\title{
Book Review: A Short Course for Career Progression
}

\author{
Career Advice for Life Scientists, by the Women in Cell Biology Committee (Elizabeth \\ Marincola, Vol. Ed.); 105 pp.; 2002; American Society for Cell Biology (Bethesda, MD); \\ http://www.ascb.org
}

Reviewed by Kathryn G. Miller, Washington University

Submitted September 16, 2002; Accepted September 17, 2002

The American Society for Cell Biology (ASCB) recently published a short collection of essays entitled Career Advice for Life Scientists. This useful book is drawn from the Women in Cell Biology (WICB) column in the ASCB monthly newsletter. The WICB column has long been a highlight of the newsletter for many readers. It routinely discusses issues of interest to life scientists. Although a few essays both in the columns and in the compilation deal specifically with issues related to being a woman in science, most provide valuable advice and insight equally applicable to men and women. The editors of the book (Elizabeth Marincola, Executive Director of the Society, and the members of WICB) selected the columns that they judged to give the best advice in a number of areas important for success in science, including promotion strategies, lab management, and career-family balance. Each essay is only a few pages long, providing a succinct summary of relevant and useful information. The short format means that one or two essays can be read in 10-15 min, so they fit nicely as a break between other more lengthy tasks. Most essays are structured to give practical advice for everyday living as a life scientist-and most accomplish this goal remarkably well. This book should be required reading for lab heads and graduate students alike.

Much of what is in this book would be beneficial reading for scientists beyond those in the life sciences. It was difficult to find essays that were so tailored to life scientists that they did not contain significant valuable advice or information for any scientist. The essays in the sections "Women \& Science Careers" and "Under-representation in Science Careers" and the essay "The Scholarship of Teaching" are written from the perspectives and experiences of life scientists about science careers, but they are not specific to life scientists. Several articles on management ("A Crash Course in Management," "Successful Negotiation") and communication ("Communicating Effectively at Department Meetings," "And Our Next Speaker Is...") and the interesting piece "Dealing with Unstable Colleagues" contain nothing that is specific to life science and contain insights valuable to any academic. The specifics described in some essays ("Getting the Most from Your Graduate Experience," "Research at a Small Institution,"

DOI: $10.1187 /$ cbe.02-09-0044

Corresponding reviewer. E-mail address: miller@biology.wustl. edu.
"Earning Tenure") conform best to the career structures, demands, and expectations that are typical for life scientists, but even these have much that is applicable to other disciplines, both scientific and nonscientific. Only one essay, "Breaking into Biotech," seems mainly applicable to individuals in biology and biomedical fields.

This book should be highly relevant to life scientists at all levels and with a wide variety of interests and career goals. Although not every piece of advice is directly applicable to all career stages, each essay provides a point of view or information about a topic that will benefit scientists at all stages. A senior investigator might not be personally interested in the chapters on alternative careers ("Research at a Small Institution," "Breaking into Biotech," "Teaching Science in High School"), but students and postdocs in their labs may be interested in such alternatives. The essays provide good information on what it takes to be successful in several "nontraditional" careers, highlight some of the reasons for seeking these careers, and describe the different types of rewards that can be experienced. These essays should help students and advisors structure training programs to better prepare students seeking such careers. Likewise, the advice on gaining tenure may no longer be applicable to the senior scientist, but such a person may be involved in mentoring others. The information in these essays provides a useful perspective for mentors as well as students being evaluated.

The authors come from the Society staff and membership; some are WICB committee members, but many are not a part of that group. Each author brings some personal and professional expertise to the issue. Thus, the advice in the book goes beyond what any one author's perspective or experience would be able to provide. A number of essays include references or are compilations of informal surveys of colleagues, which indicates that the authors have attempted to synthesize a wider perspective. In general, these are not merely one scientist's thoughts on a subject, but well-researched and well-thought-out, logical approaches to the problems and issues that arise in academic careers. Uniformly, the essays are thoughtfully written and thought provoking.

The book is organized into sections that contain two to three essays on related themes. Some particularly obvious themes are tenure, parenthood and science, and communication, but intriguingly, others are less obvious. My personal favorite is the first section entitled "The Head Game." In this section, three essays explore different aspects of mental machinations 
relevant to careers in the life sciences. In the first, "The Imposter Phenomenon" is explored. How many established, successful scientists recall a time during their careers when they doubted their own abilities and believed that they had "fooled everyone" into thinking they were qualified for or even talented in pursuit of science as a career? Many graduate students and postdocs, who may be thinking along these lines at this moment, may find this surprising, but research supports the notion that many successful scientists have experienced this phenomenon at some time during their career. By presenting factual information on this issue, this essay provides perspective for both mature, successful scientists and younger colleagues who have experienced these feelings. Even more important is that this essay contains practical suggestions about how to combat this potentially debilitating self-perception. This advice could be helpful not only to victims of this phenomenon, but also to mentors trying to help the students and young colleagues they interact with to overcome it.

This section also includes practical advice about when to accept and when and how to decline requests for expenditure of time and energy ("Saying 'No"). This essay nicely lays out the balance between a life scientist's responsibility to contribute to the community and the importance of accepting such responsibilities to his or her career advancement, and the fact that the demands are invariably greater than the amount of time available. It summarizes some of the common motivations for saying "yes" to requests that ultimately ought to have been refused, providing a framework for understanding how to set priorities to achieve a good balance. The final article in this section discusses "Unwritten Rules for Advancement": how to find out about them, what some common rules are, and how to use them effectively.

Another essay that stands out for its interesting perspective is "Crossing to the Other Side." This essay provides insight into how it feels to move from lab member to principal investigator (PI). One day you are one of the group, then suddenly you are one of "them." The perceptions of the person "crossing over" and the perception of this person by others change dramatically in a short time. This essay is interesting reading, whether the reader has gone through the transition or has yet to do so.

The essays that deal with lab management are some of the most useful to the majority of scientists. Few scientists have any training in management, and many find dealing with people in their labs the most difficult part of being researchers. One section is devoted to "Management," which includes chapters called "A Crash Course in Management," "Designing Productive Lab Meetings," and "Some Tips on Successful Negotiation." All these chapters include practical suggestions for improving the running of labs and interpersonal relationships in the work environment to make everyone more productive. Several chapters in other sections of the book provide complementary information: "Creative Mentoring Strategies" and "Dealing with Unstable Colleagues" are two of these.

One theme that runs through the book is the importance of mentoring. Only one essay formally addresses this topic-
"Creative Mentoring Strategies"—but many others highlight the impact of mentoring. Mentors can be of help in dealing with the Imposter Phenomenon. In addition, it is obvious to most scientists that progressing toward tenure is facilitated by having a mentor who can help define institutional expectations and provide advice on what to do and what not to do ("Earning Tenure: Ten Recommendations"). It might be less obvious that becoming a mentor might also be an important part of what is evaluated (and valued) by those deciding on a promotion ("The Tenure Process Viewed from the Top"). Mentoring both by a thesis advisor and by others who have expertise, experience, and interests that are different from the thesis advisor's can be an important part of graduate education ("Getting the Most from Your Graduate Experience"). The importance of mentoring is also addressed in "Unwritten Rules for Advancing Your Career" and several other essays, at least in passing.

For graduate students, this book contains a great deal of useful information. "Getting the Most from Your Graduate Experience" is directly aimed at this population. As mentioned previously, "The Imposter Phenomenon" is often applicable to this stage. The essays on different careers (in the sections "Exploring Venues for Science" and "Teaching Science in High School") are also important, even for students not currently considering careers in these areas. These essays broaden a student's perspective on the possibilities for the future. Besides these directly applicable essays, those that deal with management, communication, and negotiation provide information that will be important in the near future and give a taste of what life will be like as an independent scientist. Along the same lines are "Crossing to the Other Side" and the section entitled "Tenure." Understanding what is required for success and what changes with each career stage will certainly help students prepare and make decisions about their future.

Even the few essays that deal specifically with "Women in Science Careers," such as "Shaping the Future of Women in Science" and "Why Women Leave Science" provide a useful perspective for men and women alike. In particular, the information in "Why Women Leave Science" is especially important for anyone who is serious about training, hiring, retaining, and promoting excellent women scientists. Gaining an understanding of issues that influence decision making by women in science is important for persons (mostly men) in powerful and influential positions. In addition, the essay "Increasing Representation of People of Color in Science" describes the success of a program to introduce young Hispanic women to professional careers. This program is one that could be emulated more widely to better bring people from many diverse backgrounds into scientific careers. Established scientists in many institutions should be aware of how successful such strategies can be.

There are many places in the book where readers will say, "I felt like that" or "I never looked at it from that perspective" or "I didn't realize that!" These creative, insightful, and useful explorations of issues of interest to scientists are valuable tools in negotiating the path to success. The ACSB and WICB have done a great job of assembling a resource likely to be useful to all scientists. 